\title{
Lur’e 問題の観点からみたスライディングモード制御系に関する一考察
}

\author{
岡 林 亮 爾*·古田勝 久*
}

A Note on Sliding Mode Control Systems from the Viewpoint of the Lur'e Problem

Ryoji OKabaYashi* and Katsuhisa Furuta*

\begin{abstract}
The conventional sliding mode control (SMC) theory assumes the discontinuous control law, therefore the dynamical system describing the closed loop doesn't satisfy the Lipschitz condition. In this note, we consider the SMC system assuming the continuous control law, and analyze the stability and the robustness from new viewpoints.
\end{abstract}

Key Words: sliding mode control, Lur'e problem, loop transformation

1.はじめに

スライディングモード制御（Sliding Mode Control, 以下 $\mathrm{SMC}$ と略す) は，入力端外乱および適合条件を満たすシス テムのパラメータ変動に対して優れたロバスト性を有する非 線形制御手法として広く認知されており，ロボットをはじめ とする実システムへの応用も積極的に行なわれている ${ }^{1)}$. し かるに，この手法は理論上制御則として不連続非線形関数で ある符号関数 $\operatorname{sign}(\cdot)$ を用いることを前提としており，その結 果閉ループ系を記述する動的システムはいわゆる Lipschitz 条件を満たさず，したがって解の存在・一意性は保証されな い.この問題に対しては, Filippov ${ }^{2)} に よ る$ 微分方程式論を 用いて一応の理論的説明はなされているものの，やや難解な こともあり，一般によく知られているとはいい難い.

一方，SMC を実装する場合は，理想的な不連続信号を制 御入力に用いることは通常不可能であるとか, 符号関数を直 接実装しようとすればいわゆるチャタリング現象を引き起こ すなどの理由により，元の制御則を修正して符号関数を飽和 関数やシグモイド関数に置き換えることが一般的である ${ }^{1)}$. しかるにその場合は厳密な意味で SMC ではなくなるにも関 わらず，たいていの場合，実験結果あるいはシミュレーショ ン結果から十分な性能を得ている(から問題ない) という説 明がなされるのみであり，最初から修正制御則を前提とした 場合の閉ループ系の安定性やロバスト性に関する理論的説明 はこれまでほとんどなされていない。

本論文では, 線形システムに対して制御則に最初から不連 続符号関数ではなく，連続飽和関数を用いることを前提とし た場合の SMC 系を考察する。この場合，閉ループ系を記述 する動的システムは Lipschitz 条件を満たし，また閉ループ 系を Lur'e 系 ${ }^{3)}$ に帰着させることにより大域的漸近安定性も 理論的に㙜付けられることを示す．また閉ループ系にループ 変換を施すことにより，SMC の特徴であるロバスト性に関

* 東京工業大学 東京都目黒区大岡山 2-12-1

* Tokyo Institute of Technology, Meguro-ku, Tokyo (Received November 9, 1998)

(Revised February 5, 1999)

しても新たな視点からの説明が可能となることを示す.

\section{Lur'e 問題への帰着と大域的漸近安定性の証明}

1 入力線形システム

$\dot{x}=A x+B u$

（ただし $A \in R^{n \times n}, B \in R^{n \times 1},(A, B)$ は可制御）に対し，制 御則

$$
\begin{aligned}
& u=-(S A x+K \operatorname{sat}(\sigma / \varepsilon)+\alpha \sigma) \\
& \sigma:=S x, \quad S \in R^{1 \times n}
\end{aligned}
$$

を考える．ただ $S B=1$ かつ $S x=0$ :安定となるように $S$

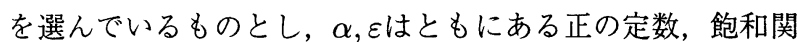
数 $\operatorname{sat}(\cdot)$ は

$$
\operatorname{sat}(e):=\left\{\begin{array}{cl}
+1 & , \quad e \geq 1 \\
e & , \quad|e|<1 \\
-1 & , \quad e \leq-1
\end{array}\right.
$$

と定義されるものとする(注1).

（2）を（1）に代入すると,（1）の右辺は明らかに Lipschitz 連続となり, 従来の微分方程式論 ${ }^{4)}$ の範囲内で解の存在 $\cdot$ 一意 性が保証される。現実に実装される SMC 則は，制御則（1） において正定数 $を$ を適当に選んだものに対応する.

さて,(2)を用いた閉ループ系に対してつぎの定理が成り立 ち, Lur'e 問題 ${ }^{3)}$ の枠組に帰着されるとともに, 任意の $\epsilon>0$ に対して大域的漸近安定性が保証される。

《定理 1》

（1）システム（1）に対する制御則（2）による閉ループ 系は, 線形部

$$
\begin{aligned}
\dot{x} & =\bar{A} x+B v \\
\sigma & =S x
\end{aligned}
$$

と非線形部フィードバック

$$
v=-\phi(\sigma)
$$

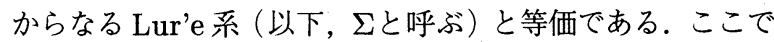

(注 1) $\operatorname{sat}(\sigma / \varepsilon)$ を $\operatorname{sign}(\sigma)$ と置き換えれば通常の SMC 則と一 致する ${ }^{1)}$. 


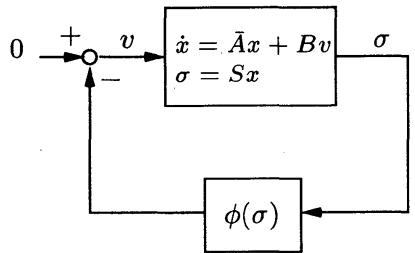

Fig. 1 Closed loop $\Sigma$.

$$
\begin{aligned}
& \bar{A}:=A-B S(A+\alpha I) \\
& \phi(\sigma):= \begin{cases}+K & , \quad \sigma \geq \varepsilon \\
K / \varepsilon & , \quad|\sigma|<\varepsilon \\
-K & , \quad \sigma \leq-\varepsilon\end{cases}
\end{aligned}
$$

である（Fig.1）。

（2）Lur'e 系 $\Sigma$ の線形部（4）において $(\bar{A}, B)$ は可制御, $\bar{A}$ は Hurwitz 行列, および $v$ おら $\sigma$ までの伝達関数は強正 実である。一方, 非線形関数 $\phi(\sigma)$ はセク夕 $[0, \infty)$ に含ま れる。

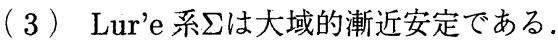

(証明)

（1）閉ループ系を変形することにより明らか

（2） $(\bar{A}, B)$ の可制御性は $(A, B)$ の可制御性より明らか. システム（1）において一般性を失うことなく可制御正準 形を考えると，

$$
\begin{aligned}
A & =\left[\begin{array}{cccc}
0 & 1 & \cdots & 0 \\
\vdots & \vdots & \ddots & \vdots \\
0 & 0 & \cdots & 1 \\
-a_{0} & -a_{1} & \cdots & -a_{n-1}
\end{array}\right], \\
B & =\left[\begin{array}{llll}
0 & \cdots & 0 & 1
\end{array}\right]^{T}, \\
S & =\left[\begin{array}{llll}
c_{0} & \cdots & c_{n-2} & 1
\end{array}\right]
\end{aligned}
$$

$\left(s^{n-1}+c_{n-2} s^{n-2}+\cdots+c_{1} s+c_{0}:\right.$ Hurwitz 多項式 $)$

とおけ，これらを（6）に代入すると

$$
\begin{aligned}
& \operatorname{det}(s I-\bar{A}) \\
= & (s+\alpha)\left(s^{n-1}+\cdots+c_{1} s+c_{0}\right)
\end{aligned}
$$

および

$$
\begin{aligned}
G(s) & :=S(s I-\bar{A})^{-1} B \\
& =\frac{1}{s+\alpha}
\end{aligned}
$$

を得，これより

$$
\operatorname{Re} G(j \omega)>0, \quad \forall \omega \in R
$$

を得る。一方， $\phi(\sigma)$ がセク夕条件 ${ }^{3)}$ を満たすことは明らか. （3）（2）の結果およびPopov 条件 ${ }^{5}$ より, 容易に導か れる。

定理 1 の結果より，従来 SMC において“境界層の導入” 1) として用いられてきた修正制御則（2）による閉ループ系は， 任意の $\varepsilon>0$ に対して大域的漸近安定性が保証される。また，

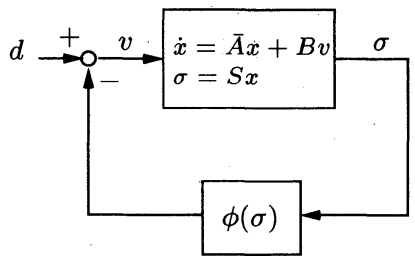

Fig. 2 Closed loop $\Sigma_{d}$.

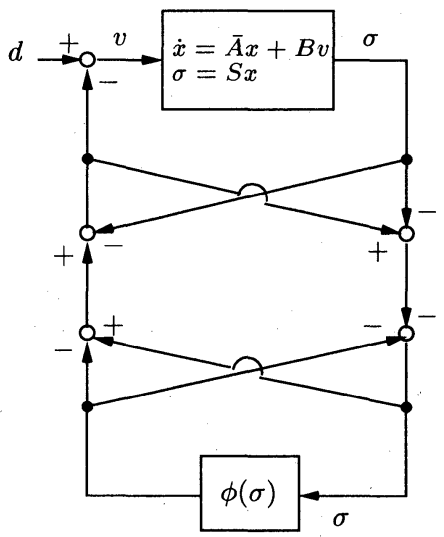

Fig. 3 Equivalent closed loop $\Sigma_{e 1}$.

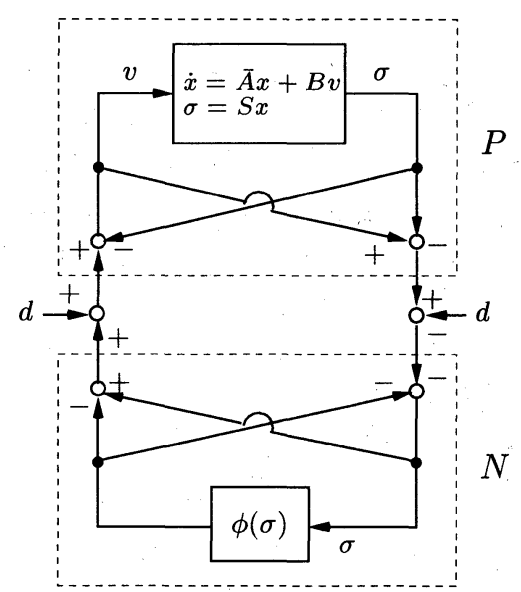

Fig. 4 Equivalent closed loop $\Sigma_{e 2}$.

飽和関数の代わりにシグモイド関数を用いた場合に対しても 同様の証明が可能である。

\section{3. ループ変換によるロバスト性解析}

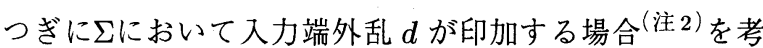
え，これを $\Sigma_{d}$ とする $\left(\right.$ Fig. 2) . $\Sigma_{d}$ に対してループ変換 3 ) を施すと，等価な閉ループ系として $\Sigma_{e 1}(\mathbf{F i g . 3})$, 更に $\Sigma_{e 2}$ （Fig.4）を得，これよりつぎの定理を得る。

《定理 2》系 $\Sigma_{d}$ は，系 $\Sigma_{d}^{\prime}($ Fig. 5) と等価である。ここで線 形部 $P(s)$ は有界実であり，非線形部 $N$ は関数：

$$
N(e)=\left\{\begin{array}{cl}
-e+2 K & , \quad e \geq K+\varepsilon \\
\frac{K-\varepsilon}{K+\varepsilon} e & , \quad e<|K+\varepsilon| \\
-e-2 K & , \quad e \leq-K-\varepsilon
\end{array}\right.
$$

（注 2）適合条件 1)を満たすシステムのパラメータ変動に関して も, その影響は等価的に入力端外乱の一種とみなしうる. 


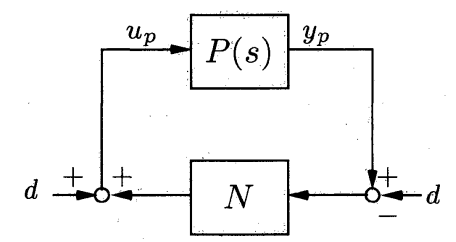

Fig. 5 Closed loop $\Sigma_{d}^{\prime}$.

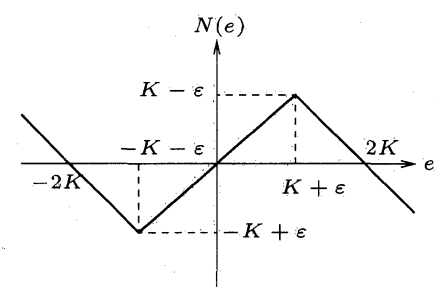

Fig. 6 Nonlinear function $N(e)$.

である（Fig.6）。

（証明）系 $\Sigma_{e 2}$ (Fig. 4) より

$$
P(s)=(1-G(s))(1+G(s))^{-1}
$$

を得, $G(s)$ が強正実であることから $P(s)$ は有界実となる ${ }^{6)}$. また， $\Sigma_{e 2}$ および（7）より（14）を得る.

Fig.5 からわかる通り，系 $\Sigma_{d}$ に入力端外乱が印加すること は, 系 $\Sigma_{d}^{\prime}$ の線形部 $P(s)$ の入出力両端に絶対值が等しくかつ 符号が相異なる外乱が同時に印加することと等価である.

特に $\Sigma_{d}^{\prime}$ において, 線形部 $P(s)$ の出力 $y_{p}$ がある正数 $\delta(<K)$ に対して $\left|y_{p}\right|<\delta て ゙$, 外乱 $d か ゙ ~|d|<K-\delta$ を満たす場合を 考える(注 3$)$.このとき, 非線形部 $N$ は事実上線形関数：

$$
N(e)=\frac{K-\varepsilon}{K+\varepsilon} e
$$

とみなせるが, このとき, 線形部 $P(s)$ への入 $u_{p}$ は

（注 3） $\Sigma_{d}$ において $G(s)$ の状態がスライディングモード上にあ ることは， $\Sigma_{d}^{\prime}$ において $y_{p}=0$ であることに対応する.

$$
\begin{aligned}
u_{p} & =N\left(y_{p}-d\right)+d \\
& =\frac{K-\varepsilon}{K+\varepsilon} y_{p}+\frac{2 \varepsilon}{K+\varepsilon} d
\end{aligned}
$$

となり, (2) において $\varepsilon>0$ を小さく選べば選ぶほど外乱 $d$ の 影響が低減されることがわかる。このことは SMC 理論でよ く知られた “スライディングモードにおける入力端外乱の完 全除去性能”にまさしく対応している。

\section{4. おわりに}

本論文では, 制御則において最初から連続飽和関数を用い ることを仮定した場合のスライディングモード制御系につい て考察した。このとき, 閉ループ系を記述する動的システム は Lipschitz 条件を満たし, 従来の微分方程式論の範囲内で 解の存在・一意性が保証されるとともに, 閉ループ系を Lur'e 系に帰着させることにより，大域的漸近安定性も保証され ることを示した．更にループ変換を施すことにより，スライ ディングモード制御の特徴であるロバスト性に関しても新た な観点からの説明が可能となることを示した。

$$
\text { 参 考 文 献 }
$$

1）野波，田：スライディングモード制御，コロナ社（1994）

2) A. F. Filippov: Differential Equations with Discontinuous Right-hand Side, Amer. Math. Soc. Trans., 42-2, 199/231 (1964)

3) M. Vidyasagar: Nonlinear Systems Analysis (2nd ed.), Prentice-Hall, (1993)

4）高橋：微分方程式入門, 東京大学出版会（1988）

5) J. -J. E. Slotine and W. Li: Applied Nonlinear Control, Prentice-Hall, (1991)

6）前田：正実性と回路網，計測と制御，34-8，662/670（1995） 